\title{
Intraspecific genetic structure in a mixed population of Quercus petraea (Matt.) Leibl and $Q$. robur $L$.
}

\author{
R. BACILIERI $\dagger \ddagger, T$. LABBE† \& A. KREMER $\dagger *$ \\ †l.N.R.A., Laboratoire de Génétique et d'Amélioration des Arbres Forestiers, B.P. 45, 33610 Gazinet, Cestas, France and \\ $\ddagger$ /stituto di Selvicoltura, University of Florence, Via San Bonaventura 13, 50145 Firenze, Italy
}

\begin{abstract}
The intraspecific genetic structure of a mixed population of sessile and pedunculate oak was studied in the Petite Charnie Forest, Sarthe, France, using enzyme electrophoresis. Spatial structure was analysed by calculating $F$-statistics and autocorrelations at different scales of spatial subdivision of the population. $F$-statistics were also used to compare the genetic structure of groups of trees subdivided according to the phenology of flowering. Spatial organization of phenology of flowering was studied with autocorrelation methods. In both species, a highly significant heterozygote deficiency was found at the population level. Spatial genetic structure was at least partially responsible for this deficiency, as demonstrated by the variations observed in $F$-statistics in relation to the size of this population subdivision. The significance of the observed structure was confirmed by comparison with a null hypothesis generated with the help of permutation analysis. We suggest that the limited dispersal of pollen and/or seeds in the stand gave rise to a family structure. The autocorrelation in phenology of flowering found in both species could contribute to lower the neighbourhood size and then to increase the Wahlund effect. Autocorrelation analyses allowed us to show that heterogeneity of patterns of structure among loci was present. Other possible causes of the genetic structure and its heterogeneity are discussed.
\end{abstract}

Keywords: allozymes, autocorrelation, $F$-statistics, genetic structure, phenology of flowering, Quercus.

\section{Introduction}

Many tree species are characterized by a high genetic diversity (Hamrick et al., 1992). Until now, studies on spatial distribution of diversity have focused mainly on the pattern of variation over widespread geographical zones (Wheeler \& Guries, 1982; Dancik \& Yeh, 1983; Ledig \& Conckle, 1983; Kremer et al., 1991). Recent work has shown that within tree populations, in many cases, gene diversity is not randomly distributed (Knowles, 1991; Perry \& Knowles, 1991; Sork et al., 1993).

Spatial structure can result (1) from selection for adaptative traits in an heterogeneous environment, (2) from genetic drift when dispersal is restricted or (3) from founder events and subsequent migration (Sokal, 1978). Temporal heterogeneity in gene frequencies of gamete and zygote pools can be induced by variation in flowering time or fecundity within a population (Gregorius et al., 1986; Fripp et al., 1987; Sampson et

\footnotetext{
*Correspondence.
}

al., 1990). Differentiation on a relatively small scale, loss of alleles caused by genetic drift and/or a certain amount of inbreeding may appear within populations as a consequence of the different types of driving force.

A description of the genetic structure of populations is necessary for an understanding of their evolutionary dynamics. A practical consideration of such knowledge concerns, for example, the method of sampling genetic diversity. Additionally, in many types of studies, concerning, for example, the estimation of mating system parameters (Ritland, 1985) or additive genetic variance (Squillace, 1974) from open-pollinated progenies, the inferences that can be made will be biased in the case of a non random distribution of genotypes.

Quercus petraea (Matt.) Liebl. and Quercus robur L. are the two most abundant deciduous tree species in France, together covering about 30 per cent of the total forested area. They are almost completely outcrossing species (Bacilieri et al., 1993), and exhibit a level of allozyme diversity which is among the highest of all woody species (Kremer et al., 1991). Moreover, in 
both species a major component of the total diversity (95-99 per cent of $H_{\mathrm{t}}$ ) is confined within populations. This is the expected pattern of gene diversity for species in which long life span, outcrossing and long distance dispersion of pollen by wind allow for a large gene flow among populations. However, to date very little is known about how this major component of diversity is distributed within populations.

Different methods are available to study the genetic structure of populations: for allozyme data, the most frequently used are Wright's $F$-statistics (Wright, 1943) and spatial autocorrelation analysis (SAA; Sokal \& Oden, 1978; Epperson \& Clegg, 1986). F-statistics, being based on a genetic model of correlation of genes within individuals and populations, would appear the best suited for the study of genetic variation. However, the estimates are generally affected by large error variances and are not always sensitive enough to detect patterns of spatial structure at the subpopulation level (Heywood, 1991). On the other hand, SAA is a method that affords statistical correlation between proximal individuals regardless of the genetic mechanisms involved.

In the present paper, both methods were used to examine the organization of variability in a mixed stand of sessile and pedunculate oaks. Using allozyme data, we calculated $F$-statistics and autocorrelations at different scales of spatial subdivision of the population. $F$-statistics were also used to compare the genetic structure of phenological groups.

Autocorrelation in the phenology of flowering, measured directly on adult trees, was also studied. Under natural conditions, we could not separate genetic from environmental effects. Nevertheless, autocorrelation in phenology of flowering, independently of the forces involved, could have an important effect on the mating system and then, in the long term, on the organization of genetic diversity.

\section{Materials and methods}

The population studied was a mixed adult stand of $Q$. petraea and $Q$. robur located in northwest France, near Le Mans. The study area was approximately 5 ha, with a uniform slope forming an ecological gradient, from a silt and sand soil in the upper zone of the stand to a clay soil with a superficial hydromorphic layer in the lower zone. The density of the stand was homogeneous, although the spatial distribution of species followed their ecological preferences: sessile oak was more abundant in the upper zone, with a density of 59 trees/ha, and pedunculate oak was predominant in the lower and more humid zone of the site, with a density of 57 trees/ha. A mixed zone, representing approxi- mately 45 per cent of the area, was located in between the upper and lower zones, where both species were mixed tree by tree.

All trees present in the stand were mapped and classified as either one or the other oak species with the help of a Factorial Discriminant Analysis on 40 morphological leaf characters (R. Bacilieri, unpublished data). Winter buds were then collected to extract enzymes. A total of 190 sessile and 217 pedunculate oaks was sampled and assayed for seven enzymatic systems: 19 trees of the stand were excluded since these were either morphologically intermediate between the two species (12 trees) or the extractions were of poor quality. Extraction procedures followed those of Müller-Starck \& Ziehe (1991). The compositions of the electrode and gel buffers and the staining buffer formulations were adapted from Vallejos (1983) and Zanetto et al. (1993).

The enzymatic systems studied yielded seven loci, which showed a simple Mendelian inheritance in controlled crosses (A. Zanetto, unpublished data): $P G M-A$ (phosphoglucomutase, E.C. 3.4.11.1), $A C P-C$ (acid phosphatase, E.C. 3.1.3.2), AAP-A (alanine aminopeptidase, E.C. 3.4.11.1) and $L A P-A$ (leucine aminopeptidase, E.C. 3.4.11.1) were monomeric, $I D H$ $A$ (isocitrate dehydrogenase, E.C. 1.1.1.42) and PGI-B (phosphoglucoisomerase, E.C. 5.3.1.9) were dimeric and $M R$ (meniadione reductase, E.C. 1.6.99.2) was tetrameric.

For PGM-A and AAP-A, the presence of null alleles was suspected. In the case of LAP-A, one allele with weak activity was suspected to induce poor separation between heterozygotes and homozygotes. This could bias the estimation of heterozygote deficit $\left(F_{\text {is }}\right)$. Therefore calculations were performed on two different sets of loci: (1) the total number, and (2) the subset composed of $P G I-B, I D H-A, A C P-C$ and $M R$, for which no null alleles were suspected.

Phenological observations of flowering were made every three days in 1989. Floral development was observed in the upper part of the crown, using a telescope with $25 \times$ or $40 \times$ magnification. Male flowers were considered mature when the catkins began to release pollen and female flowers when they became receptive, indicated by a bright red-coloured pistil. For each species, the trees were grouped into three precocity classes, with an approximately equal number of individuals, on the basis of the earliest and latest date of individual male flowering.

For the analysis of spatial and temporal structure, the two species were considered separately. $F$-statistics were calculated with the method of Weir \& Cockerham (1984) that provides estimates that do not depend on the number of individuals and populations. With allo- 
zyme data, we calculated $F_{\text {st }}$ and $F_{\text {is }}$, which measured, respectively, the correlation of genes between different individuals in the same population and the correlation of genes within individuals within the population. These statistics could also be considered as estimates of differentiation among populations $\left(F_{\mathrm{st}}\right)$ and of heterozygote deficit $\left(F_{\text {is }}\right)$. Firstly, $F_{\text {is }}$ was calculated for the whole stand. For each locus, the departure from the null hypothesis of panmixia $\left(F_{\text {is }}=0\right)$ was assessed with the bootstrap method (Efron \& Tibshirani, 1991) by resampling individuals. Heterogeneity of heterozygote deficiencies among loci was examined by treating them as correlation coefficients and testing accordingly (Sokal \& Rohlf, 1981). $F_{\text {is }}$ and $F_{\text {st }}$ were then calculated for different subdivisions of the area, starting with a 10 $\mathrm{m}$ grid, which corresponded approximately to the mean distance between trees. Successive subdivisions of the population were created by increasing the grid size each time by $10 \mathrm{~m}$ up to a maximum of $120 \mathrm{~m}$, which corresponded to the subdivision of the population into four parts. Confidence intervals for the means of $F_{\text {is }}$ and $F_{\text {st }}$ values over loci, for each subdivision of the population, were obtained by bootstrapping over individuals.

To test the significance of $F_{\text {is }}$ and $F_{\mathrm{st}}$, a null hypothesis was constructed with the help of permutation analysis. Each permutation consisted of a random redistribution of genotypes over spatial coordinates. For each subdivision of the population, observed $F_{\text {is }}$ and $F_{\text {st }}$ values were compared with the distribution obtained after 1000 permutations.

To compare groups of trees showing differences in flowering times, we calculated $F_{\text {st }}$ among phenological groups and their confidence intervals were calculated with bootstrap resampling (1000 samples).

The SAA was carried out using a program of J. Cuguen (unpublished data), based on the work of Sokal \& Oden (1978), that calculates Moran's I, a coefficient of spatial autocorrelation (which varies between +1 and -1 ), for all pairs of individuals within a specified distance class as a function of distance. This program works on allelic data, assigning a weight of 0.5 to the heterozygote and a weight of 1 to the homozygote for a given allele. Correlograms for the most frequent allele for each locus (the other alleles at the same locus being not independent) were drawn plotting Moran's I against distance classes $(10 \mathrm{~m})$. SAA was also used to analyse autocorrelation in precocity of male and female flowering among trees in 1989.

To assess the overall significance of a correlogram, we used Šidák's test (Šidák, 1967), which defines a probability level $\alpha^{\prime}$, for individual tests, calculated as: $\alpha^{\prime}=1-(1-\alpha)^{1 / k}$, where $\alpha$ is set as the type I error rate (here $\alpha=0.05$ ) and $k$ is the number of statistics under consideration (Epperson \& Allard, 1989). Moreover, we considered that a given value of $I$ was significant if its standard normal deviation (SND) exceeded the limits of 1.96 or -1.96 (which corresponds to $\alpha=0.05$ ) and if the number of expected likepairs comparisons in that distance class was greater than 5, as suggested by Wagner et al.(1991).

Correlograms may be very complex and different markers may give different patterns, both because of sampling errors and stochastic processes in the population or because different forces act on different loci (Slatkin \& Arter, 1991). However, this last hypothesis as a cause of differences in correlograms in natural populations has never been proved (Barbujani, 1987; Knowles, 1991). To summarize the information provided by all the loci, under the hypothesis of neutrality of alleles, we calculated the mean of Moran's $I$ over loci, for each distance class.

\section{Results}

\section{Spatial structure}

For both species, five out of the seven loci showed a highly significant heterozygote deficit at the population level (Table 1). The mean $F_{\text {is }}$, calculated over all seven loci, was highly significantly positive in adult trees of both $Q$. petraea and $Q$. robur. The test of heterogeneity of $F_{\text {is }}$ values revealed that in both species there was significant heterogeneity among loci (sessile oak: $\chi_{6}^{2}=49.76, P<0.001$; pedunculate oak: $\chi_{6}^{2}=46.13$, $P<0.001)$. When the same test was calculated excluding $P G M, A A P$ and $L A P$, the loci in which we suspected an artificial heterozygote deficit due to the presence of null alleles, again we found heterogeneity among loci, although at the limit of the significance level (sessile oak: $\chi_{3}^{2}=8.32, P=0.0417$; pedunculate oak: $\chi_{3}^{2}=7.84, P=0.0496$ ).

When the mean of $F_{\text {is }}$ was calculated for only $P G I$ $B, I D H-A, A C P-C$ and $M R$, it gave smaller values in both species but remained highly significantly positive in sessile oak and significantly positive in pedunculate oak (Table 1). Sessile oak showed a heterozygote deficiency significantly greater than pedunculate oak. The pattern of heterozygote deficit observed over loci remained substantially the same even when the 12 morphologically intermediate trees were included in the calculation with either of the species.

Single-locus $F$-statistics were not useful for the analysis of structure as the coefficients of variation obtained in bootstraps were too large, especially in the first distance classes (when the population was subdivided with a grid of size 10,20 and $30 \mathrm{~m}$, the coefficient of variation was often greater than 100 per cent). 
Table 1 Values of $F_{\text {is }}$ and its confidence interval (CI 95\%) for sessile and pedenculate oaks

\begin{tabular}{|c|c|c|c|c|c|c|}
\hline \multirow{3}{*}{$\frac{\text { Locus }}{P G I-B}$} & \multicolumn{3}{|c|}{ Sessile oak } & \multicolumn{3}{|c|}{ Pedunculate oak } \\
\hline & \multirow{2}{*}{$\begin{array}{c}F_{\text {is }} \\
0.115\end{array}$} & \multicolumn{2}{|c|}{ CI $95 \%$} & \multirow{2}{*}{$\begin{array}{l}F_{\text {is }} \\
0.021\end{array}$} & \multicolumn{2}{|c|}{ CI 95\% } \\
\hline & & -0.004 & 0.228 & & -0.073 & 0.123 \\
\hline$P G M-A$ & 0.224 & 0.073 & 0.367 & 0.329 & 0.229 & 0.427 \\
\hline$I D H-A$ & 0.126 & -0.012 & 0.259 & -0.030 & -0.117 & 0.072 \\
\hline$A C P-C$ & 0.273 & 0.151 & 0.389 & 0.182 & 0.051 & 0.309 \\
\hline$A A P-A$ & 0.301 & 0.202 & 0.402 & 0.292 & 0.205 & 0.381 \\
\hline$L A P-A$ & 0.621 & 0.508 & 0.723 & 0.504 & 0.400 & 0.611 \\
\hline$M R$ & 0.352 & 0.199 & 0.509 & 0.195 & 0.047 & 0.350 \\
\hline Mean & 0.304 & 0.259 & 0.357 & 0.244 & 0.195 & 0.288 \\
\hline $\begin{array}{l}\text { Mean of } 4 \text { loci } \\
(P G I-B, I D H-A \\
A C P-C, M R)\end{array}$ & 0.222 & 0.155 & 0.289 & 0.078 & 0.012 & 0.138 \\
\hline
\end{tabular}

Confidence intervals were calculated by resampling among individuals $(1000$ samples).

In both species, when calculated with four loci $(P G I-$ $B, I D H-A, A C P-C, M R$; Fig. 1$), F_{\text {is }}$ increased together with the size of population subdivision, and was zero when the size of subdivisions was approximately $20-30 \mathrm{~m}$ in sessile oak and $30-50 \mathrm{~m}$ in pedunculate oak. $F_{\mathrm{st}}$ was always significantly positive in sessile oak and was significantly positive in pedunculate oak starting from the first size of subdivision up to $100 \mathrm{~m}$. In both species the decrease in $F_{\text {is }}$ and the increase in $F_{\text {st }}$ observed in the first classes of subdivision were significant in comparison with confidence limits of $F_{\text {is }}$ and $F_{\text {st }}$ obtained with permutated data (Fig. 2).

The disadvantage of using $F$-statistics originated from the fact that subdivision of the area was rigid and the numbers of individuals and populations compared were limited. As a consequence, the magnitude of the variance of the single-locus estimates prohibited a comparison of patterns among the loci. In contrast, SAA gave more robust estimates when all pairs of trees within one distance class were taken into account.

In sessile oak, two alleles out of the seven analysed (the more frequent for each locus) showed a significant correlogram with Sidák's test: $A A P-A 3$ and $P G I-B 5$ (Fig. 3). For these alleles, autocorrelation was present in the first distance classes ( 10 and $30 \mathrm{~m}, A A P-A 3 ; 10$ and $40 \mathrm{~m}, P G I-B 5)$; another peak was encountered at longer distance $(70 \mathrm{~m}, A A P-A 3 ; 90 \mathrm{~m}, P G I-B 5)$. For still longer distances, autocorrelation tended to be negative.

In pedunculate oak, the patterns were quite similar to those in sessile oak. The alleles that showed signifi- cant correlograms were $P G M-A 2$ and $M R-3$ (Fig. 3), the former showing positive autocorrelation at 10 and $30 \mathrm{~m}$, the latter at 20 and $40 \mathrm{~m}$. The maximal $I$ value was 0.18 in sessile oak (PGI-B5) and 0.13 (PGM-A2) in pedunculate oak.

The correlograms of the other alleles were not significant with Sidák's test, although in some distance classes they revealed significant individual $I$ values. Sidák's test, however, is very conservative and if many loci show approximately the same pattern, they could be informative even if their correlograms are not significant. For this reason, averaging over Moran's $I$ values allows one to exploit information from all markers. In Fig. 4 a structure appeared in both species, stronger in the first distance class and then decreasing. The $I$ values in the second class fell to zero in both species (in pedunculate oak, the means of $I$ were positive at $20 \mathrm{~m}$, although no individual $I$ values were significant).

\section{Temporal structure}

In 1989, the mean length of the male flowering period was 12.0 (with a standard deviation: $\mathrm{SD}=6.75$ ) days in sessile oak and $10.6(\mathrm{SD}=6.25)$ days in pedunculate oak. Female flowering was slightly delayed in both species (5-7 days) with a mean length of 11.7 $(\mathrm{SD}=6.03)$ days in sessile and $10.1(\mathrm{SD}=4.90)$ in pedunculate oak. The groups obtained by subdividing the trees according to the phenology of flowering were formed (respectively) of 51, 51 and 60 individuals for early, normal and late flowering in sessile oak and of 


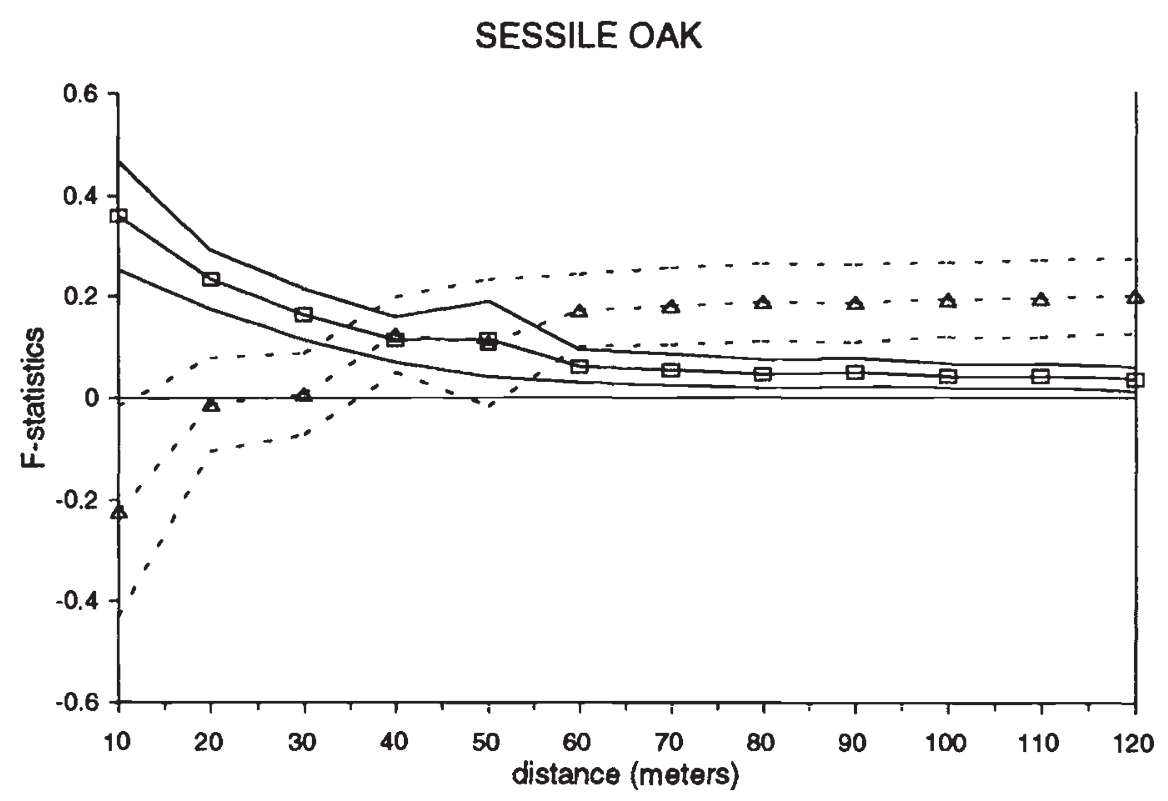

$\square$ Fst $\quad-\mathrm{Cl} 95 \%$ Fst $-\Delta$ Fis $\quad--\mathrm{Cl} 95 \%$ Fis

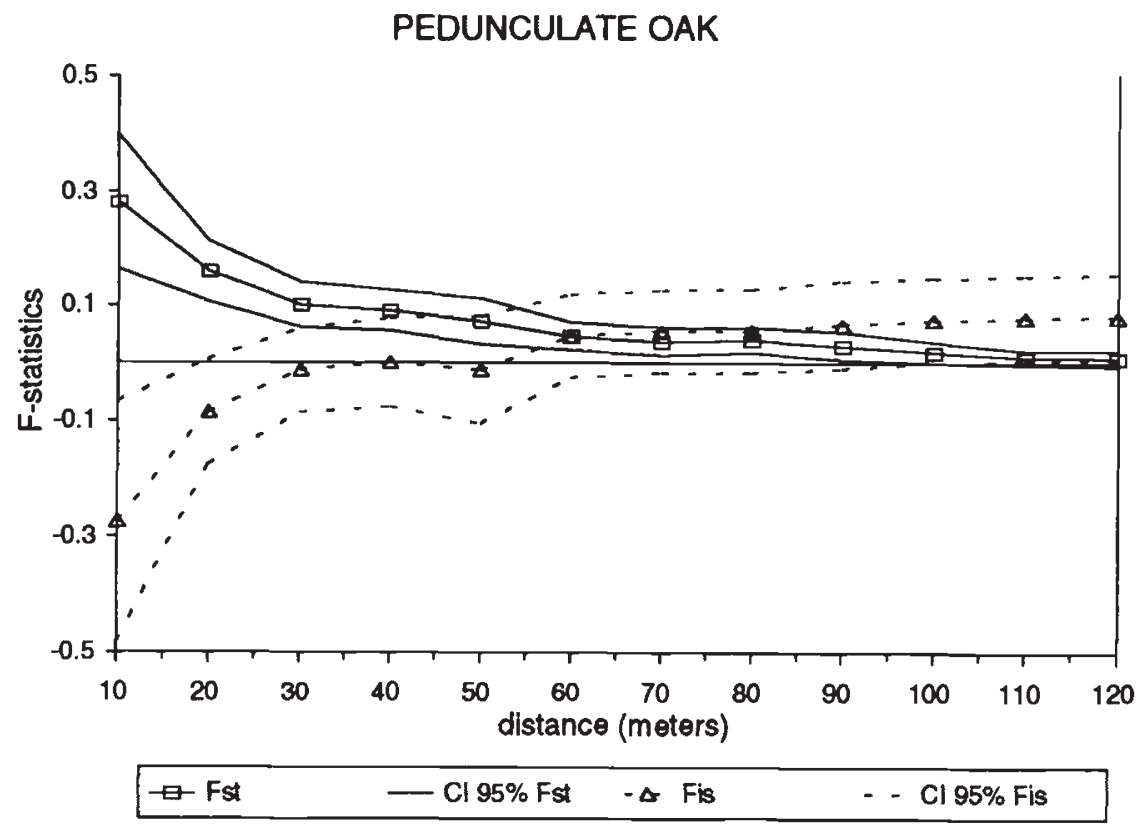

Fig. 1 Mean $F$-statistics over four loci $(P G I-B, I D H-A, A C P-C, M R)$, calculated for successive subdivisions (distance classes) of the population, in sessile and pedunculate oaks. 95 per cent confidence intervals (CI 95 per cent) were calculated by means of 1000 bootstraps over subpopulations.
57, 71 and 55 trees for early, normal and late flowering in pedunculate oak. We did not observe male or female flowering in 28 sessile and 34 pedunculate oaks; these trees were excluded from subsequent analyses.

Comparisons of the means of $F_{\text {st }}$ from allozymic data of trees subdivided phenologically clearly indicated that genetic diversity was not partitioned into phenological groups in either sessile or pedunculate oak. $F_{\text {st }}$ values were always approximately zero over all loci and they were never significantly different from zero (Table 2). The same result of absence of structure was obtained by calculating $F_{\text {st }}$ among groups of trees that, as a consequence of their differences in flowering time, could not intermate (e.g. early male flowering 


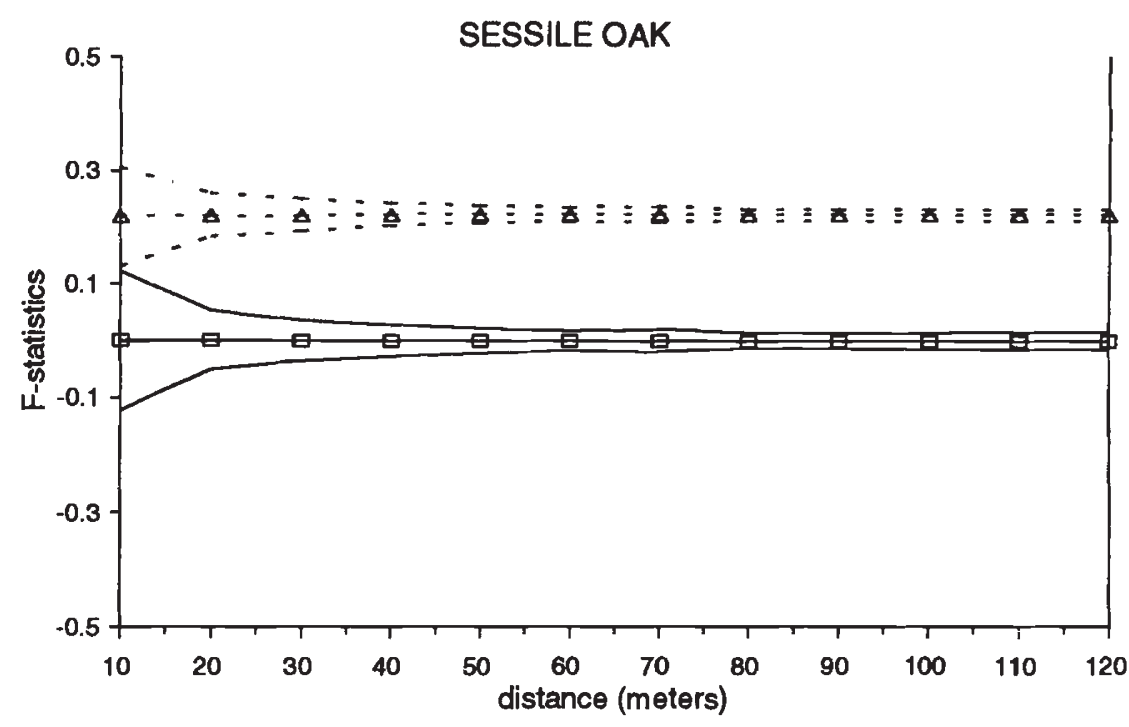

\begin{tabular}{llll|}
$\square$ Fst & $-\mathrm{Cl} 95 \%$ Fst & $-\Delta$ Fis & $-\cdots \mathrm{Cl} 95 \%$ Fis \\
\hline
\end{tabular}

Fig. 2 Mean $F$-statistics and 95 per cent confidence intervals (CI 95\%) calculated, for each distance class, after 1000 random permutations of original data. The loci used were: $P G I-B, I D H-$ $A, A C P-C, M R$.
PEDUNCULATE OAK

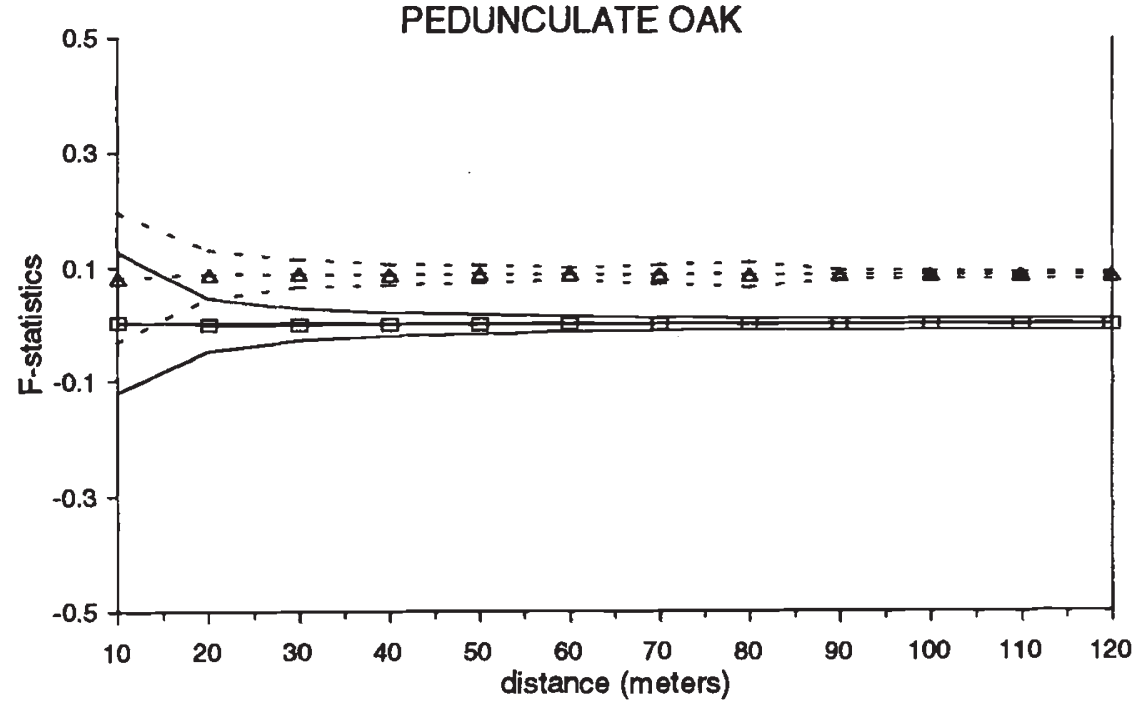

\begin{tabular}{|llll|}
\hline Fst & $-\mathrm{Cl} 95 \%$ Fst & $-\Delta$ Fis & $\cdots$ \\
\hline
\end{tabular}

with late female flowering trees, etc.; results not shown).

Nevertheless, we observed a positive spatial autocorrelation in male and female flowering phenology (Fig. 5). The individual correlograms were not significant, although significant values of SND were found in the first class in male flowering of both species and in female flowering of pedunculate oak.

\section{Discussion and conclusions}

The major results of this study may be summarized as follows: (1) allozymes reveal a large, although heterogeneous, heterozygote deficit in adult trees of sessile and pedunculate oak; in sessile oak the deficit is stronger than in pedunculate oak; (2) allozyme markers indicate that spatial structure is present, especially at 

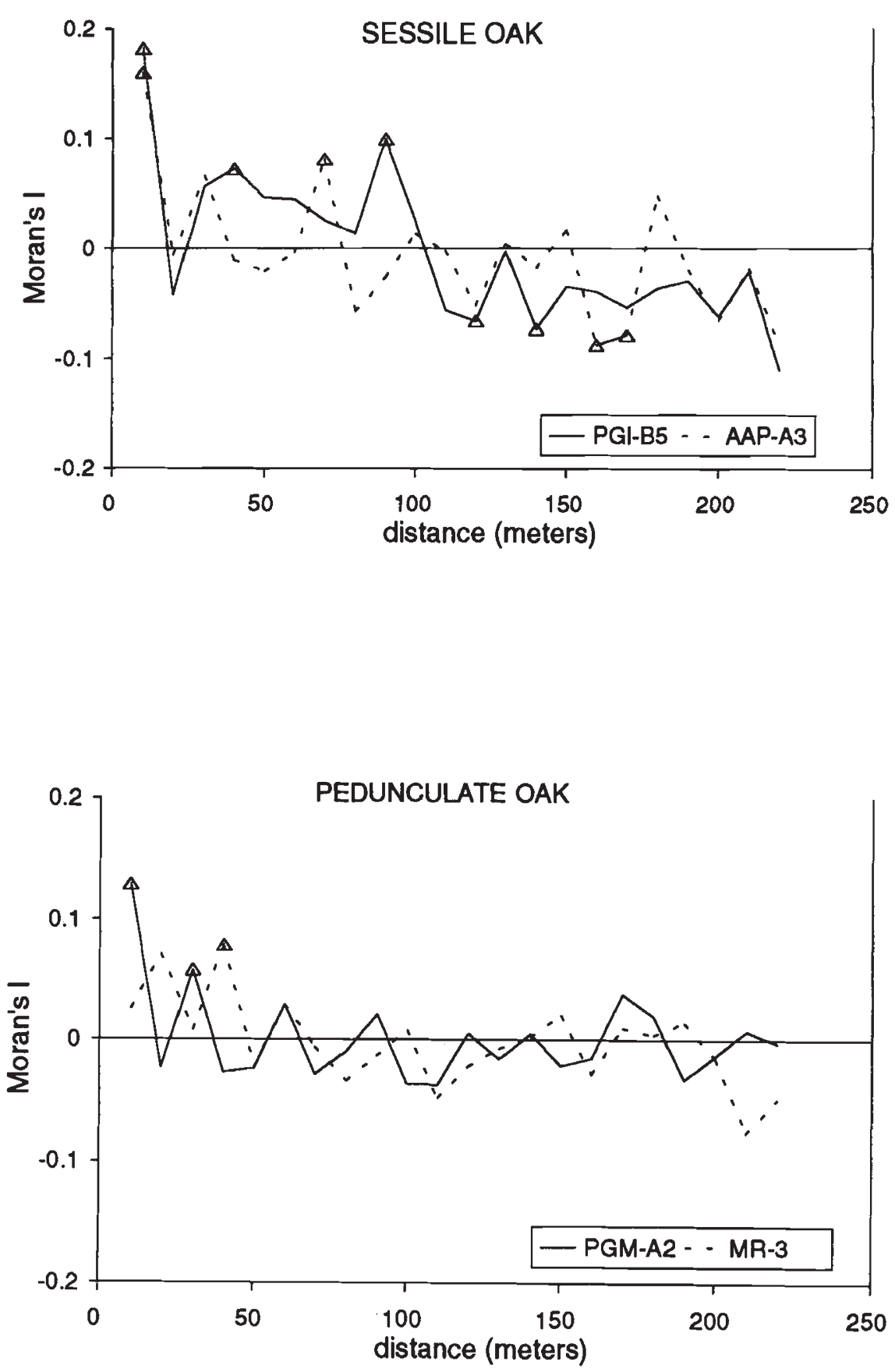

Fig. 3 Significant correlograms with Šidák's test in sessile and pedunculate oak. The symbols $(\Delta)$ correspond to Moran's $I$ with a significance level less than 5 per cent. small distances, although the pattern is not uniform over loci; this structure may partially explain the heterozygote deficiency; (3) spatial autocorrelation is also present in flowering phenology, with almost the same pattern as that occurring for allozymes; although (4) allozymic differences are not detectable among phenological groups of trees.

\section{Heterozygote deficiency}

The finding of a heterozygote deficiency by comparison to what is expected under panmixia is quite common in outcrossing species leading, together with the excess of heterozygotes in selfing species, to the concept of the heterozygote paradox (Brown, 1979). In 
Fig. 4 Mean values of Moran's I for the most frequent alleles of the seven loci.

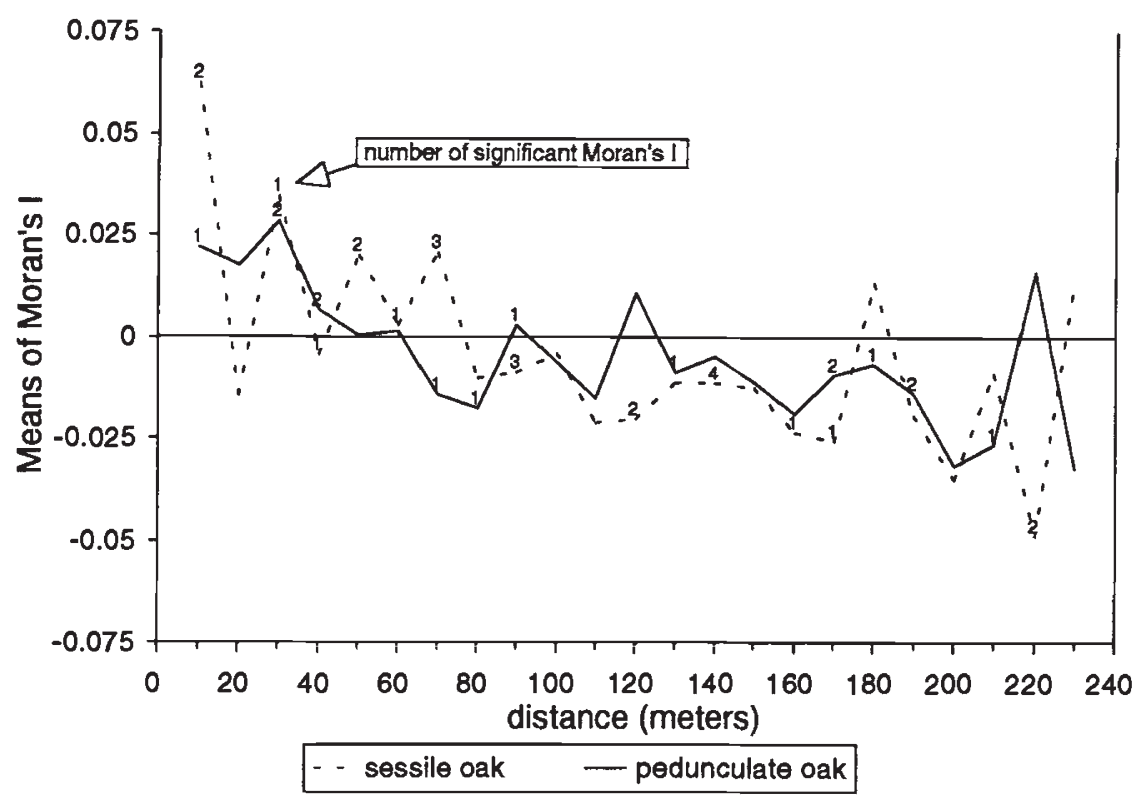

Table 2 Single-locus and mean $F_{\text {st }}$ values calculated with allozyme data among phenological groups in 1989

\begin{tabular}{lrr}
\hline Locus & Sessile oak & Pedunculate oak \\
\hline PGI-B & -0.0053 & -0.0008 \\
$P G M-A$ & -0.0008 & 0.0165 \\
$I D H-A$ & -0.0049 & 0.0062 \\
$A C P-C$ & -0.0036 & -0.0005 \\
$A A P-A$ & -0.0114 & -0.0083 \\
$L A P-A$ & -0.0153 & -0.0092 \\
$M R$ & -0.0036 & 0.0037 \\
Mean & -0.0042 & -0.0007 \\
CI 95\% & -0.0097 & -0.0057 \\
CI 95\% & 0.0009 & -0.0062 \\
\hline
\end{tabular}

Confidence intervals (CI 95\%) were obtained by resampling individuals (1000 samples).

other deciduous species of the same family (Fagaceae), as in Fagus sylvatica (Gregorius et al., 1986; Comps et al., 1990), a deficit in heterozygotes is also found, although smaller than the one observed here in sessile oak. A number of hypotheses have been proposed to explain heterozygote deficiency (Brown, 1979). Our results may be considered from this viewpoint; however, they will be considered also as a source of independent information.

\section{Spatial structure of gene diversity}

The analyses of allozyme data show that genetic spatial structure is present in the stand. In both species, the largest autocorrelations are found in the first distance class of correlograms. As autocorrelation was nearly absent in the second class $(20 \mathrm{~m})$, it is possible that the subsequent positive values in correlograms were only spurious effects due to the autocorrelation in the first class (in a correlogram, the successive values are not independent). Analysis of spatial structure is not affected by null alleles. These are generally at low frequency (as will be discussed later) and SAA were calculated only on the distribution of the most frequent alleles.

We found that SAA was more effective than the $F$ statistics to measure structure within a population on a single-locus basis because of the great interlocus variance associated with the estimation of $F_{\text {is }}$ and $F_{\text {st }}$. Despite this observation, average $F$-statistics and their confidence intervals, computed with resampling methods, confirmed that structure is present and that it can be one of the causes of the heterozygote deficiency.

The variation of allelic frequencies among subpopulations may create a heterozygote deficiency at the scale of the whole population, as has been described by Wahlund (Wright, 1978). If we assume that the observed structure is generated by limited gene flow in an isolation-by-distance model, for neutral loci and populations at equilibrium, $F_{\text {st }}$ measures the differentiation between the subpopulations due to limited gene flow and genetic drift and the size of population subdivision at which $F_{\text {is }}$ is zero may be interpreted as a measure of the panmictic unit (Wright, 1943). Under a number of hypotheses, the most important of which is that male and female dispersions are symmetrical, the panmictic unit corresponds 


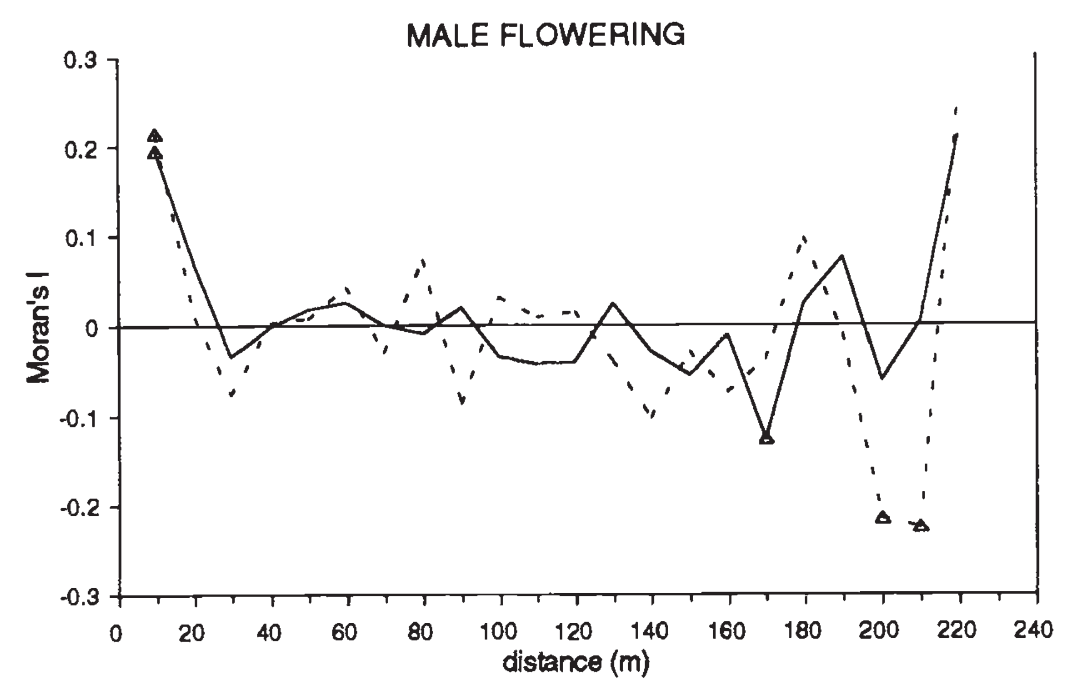

-.. sessile oak - pedunculate oak

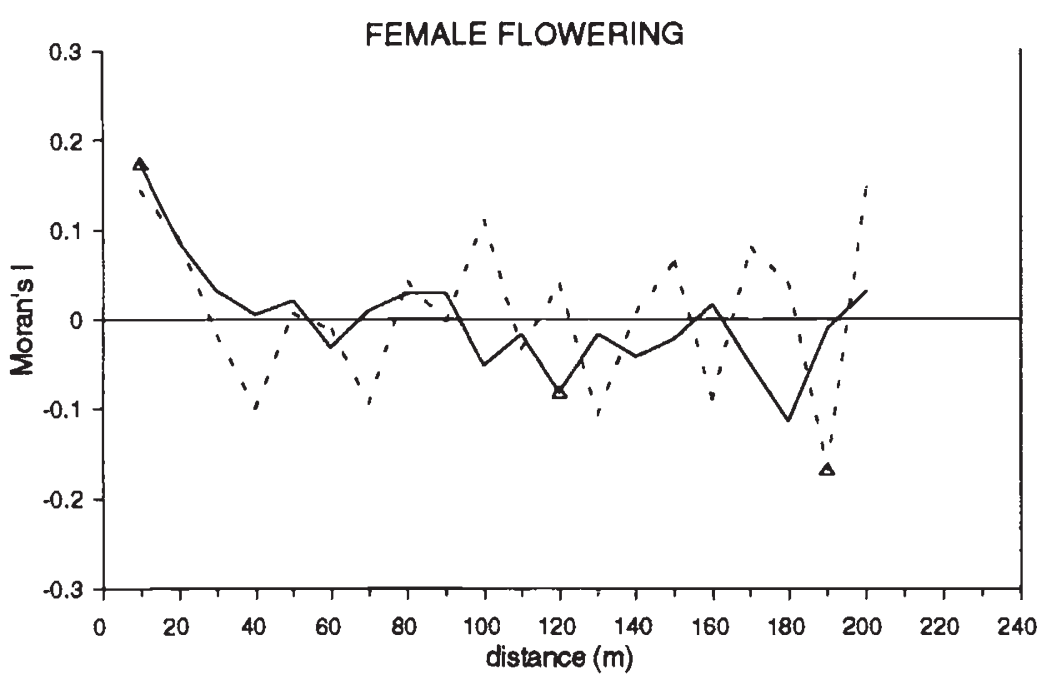

-.. sessile oak pedunculate oak
Fig. 5 Autocorrelation in phenology of male and female flowering (1989). The $\operatorname{symbols}(\Delta)$ correspond to Moran's $I$ with a significance level less than 5 per cent. to the neighbourhood size (Wright, 1943; Crawford, 1984).

It has been proven that even a very small quantity of migration between subpopulations could counter the variations in allelic frequencies due to genetic drift (Wright, 1978). On the other hand, if the contributions of individuals to following generations in a population are not constant, and at the same time dispersal is limited, a family structure will be generated (Levin \& Kerster, 1974).

In sessile and pedunculate oaks, seeds are dispersed by gravity, rodents and birds. Birds can transport acorns over great distances (Bossema, 1979) and mammals can over short distances (Jensen \& Nielsen, 1986). Both methods are presumed to be more effective in colonizing new habitats than in dense forests. In a dense forest, such as the one studied here, a major proportion of acorns falls beneath the canopy, or is dispersed over only short distances by mammals, as shown in Q. rubra (Sork, 1984). Moreover, in a dense forest, in spite of the high outcrossing rate (Bacilieri et al., 1993), and of the anemophilous pollination, fertili- 
zation may be restricted to the local pollen. We have no evidence that gene flow is limited but we suggest that limitation of seed and pollen dispersal in a dense forest may contribute to family clustering. A very similar pattern has been found with autocorrelation analysis in Quercus rubra by Sork et al. (1993). Levin \& Kerster (1974), reviewing the evidence for restricted gene flow obtained both with direct and indirect methods in a number of plant species, suggested that such an arrangement of plant populations in semi-isolated breeding units is advantageous for the evolutionary adaptation to local environments and for the storage of genetic diversity.

Autocorrelation in flowering phenology for both species supports the results obtained with allozymes for genetic spatial structure on a small scale. However, comparison between phenology and allozymes must be regarded with caution because although the former may probably have a genetic component, as has been shown in other species (Sweet, 1975; Schmidtling, 1981), it may be influenced by common environmental effects. The autocorrelation in phenology, regardless of its genetic or environmental origin, may reinforce the genetic structure and the inbreeding in the population. As a consequence, the effective population size and the neighbourhood size can be lowered (Levin \& Kerster, 1974).

\section{Other causes of structure}

Apparently, the causes that are involved in the origin of heterozygote deficiency do not act in the same way over all the enzymatic systems, as indicated by the heterogeneity of $F_{\text {is }}$ over the different loci. Part of the heterogeneity of heterozygote deficiency among loci could be generated by the presence at some of them of alleles with null or weak enzymatic activities. Following Brown (1979), the frequency of null alleles should be approximately 11 per cent at $P G M-A$ in both species and 9 per cent and 15 per cent at $A A P-A$ in sessile and pedunculate oak, respectively, to reduce $F_{\text {is }}$ to zero. For $L A P-A$, the observed $F_{\text {is }}$ would indicate that null alleles must be in frequencies greater than 25 per cent, or alternatively that, for this locus, we had mis-scored more than 50 per cent of the heterozygotes. In controlled crosses, mis-scoring of heterozygotes in the $L A P-A$ system is rare (A. Zanetto, unpublished data). On the other hand, null alleles usually occur only rarely, often $x<0.005$, although higher frequencies $(x=0.01-0.1)$ have been reported (Allendorf et al., 1982; Gardner, 1992). It would appear likely that null alleles contribute only partially to the heterozygote deficiency found in $P G M-A, A A P-A$ and $L A P-A$; for these loci there must also be other causes of the observed heterozygote deficiency.
Differences in correlogram patterns are also observed. Not all the alleles showing the strongest structure in SAA are among those with the strongest heterozygote deficiency. On the other hand, $A C P-C 2$ in sessile oak and $A A P-A 5$ in pedunculate oak show only weak and non significant autocorrelations, in spite of their high $F_{\text {is }}$ values and respective frequencies of 0.58 and 0.47 in the stand (Bacilieri et al., 1993). In view of these allelic frequencies, one would expect the $A C P-C 2$ in sessile oak and the $A A P-A 5$ in pedunculate oak to have been the most informative alleles. At this scale, it is possible that stochastic effects could be sufficient to generate dissimilarity in structure patterns between loci, as Slatkin \& Arter (1991) have shown by means of computer simulations.

Variations in the sensitivity of loci to selection pressure may also explain the interlocus differences observed with SAA and $F$-statistics. Zanetto et al. (1993) suggested that in sessile oak the loci of secondary metabolism could be more prone to selection than loci of primary metabolism. Among the loci used here, $P G I-B, P G M-A$ and $I D H-A$ are involved in primary metabolism while $A C P-C, A A P-A, L A P-A$ and $M R$ participate in secondary metabolism. Excluding $P G M$ $A$ and $A A P-A$, for which we suppose a bias in $F_{\text {is }}$ due to null alleles, in both species, at the level of the whole population, the heterozygote deficiency was smaller in $P G I-B$ and $I D H-A$ than in $A C P-C, L A P-A$ and $M R$ Adult oak stands may undergo extreme selection pressure during their life history; their populations may be reduced in number of individuals by a factor of 100 or more between the seedling and the mature stages. Therefore, in this lapse of time, even a small differential of selection (e.g. of 0.003 or less for a diallelic locus and depending on allele frequencies) against heterozygotes, in relation to homozygotes, could be sufficient to generate an heterozygote deficiency as large as the one observed. In many morphological studies, hybridization and introgression have been supposed to occur extensively between sessile and pedunculate oak (Gardiner, 1970; Rushton, 1993), although this phenomenon has never been reliably quantified. The hypothesis of hybridization is supported by the success of the interspecific controlled crosses (Aas, 1991; Steinhoff, 1993). Nevertheless, the characteristics (morphology, fertility, etc.) of the $F_{1}$ generation are still unknown. In the context of the introgression hypothesis, a selection pressure against hybrid or introgressed forms could be generated by competition with the pure species. Further studies are needed to test if selection against hybrid and introgressed forms could generate a heterozygote deficit in the two segregating populations and if this model could be applied to oaks. 


\section{Acknowledgements}

We thank R. Lumaret, R. Petit, A. Ducousso and P. Piussi for helpful suggestions on an earlier draft of this manuscript and G. Roussel for his technical aid. The work presented here was supported by a scholarship from the University of Italy and by a grant from the French Ministry of Agriculture.

\section{References}

AAS, G. 1991. Kreuzungsversuche mit Stiel- und Traubeneichen (Quercus robur L. und Q. petraea (Matt.) Liebl.). Allg. Forst-u. J.-Ztg., 162, 141-145.

ALLENDORF, F. W., KNUDSEN, K. L. AND BLAKE, G. M. 1982. Frequencies of null alleles at enzyme loci in natural populations of ponderosa and red pine. Genetics, 100, 497-504.

BACILIERI, R., ROUSSEL, G. AND DUCOUSSO, A. 1993. Hybridization and mating system in a mixed stand of sessile and pedunculate oak. In: Kremer, A., Savill, P.S. and Steiner, K.C. (eds) Genetics of Oaks, pp 122-127. Elsevier, Paris.

BARBUJANI, G. 1987. Diversity of some gene frequencies in European and Asian populations. III. Spatial correlogram analysis. Ann. Hum. Genet., 51, 345-353.

BosSEMA, I. 1979. Jays and oaks: an eco-ethological study of a symbiosis. Behaviour, 70, 1-117.

BROWN, A. D. H. 1979. Enzyme polymorphism in plant populations. Theor. Pop. Biol., 15, 1-42.

COMPS, B., THIEBAUT, B., PAULE, L., MERZEAU, D. AND LETOUREY, T. 1990. Variability in beechwoods (Fagus sylvatica L.) over central Europe: spatial differentiation among and within populations. Heredity, 65, 407-417.

CRAWFORD, T. J. 1984. What is a population? In: Shorrocks, B. (ed.) Evolutionary Ecology, pp. 135-172. Blackwell Scientific Publications, Oxford.

DANCIK, B. P. AND YEH, F. C. 1983. Allozyme variability and evolution of lodgepole pine (Pinus contorta var. latifolia) and jack pine ( $P$. banksiana) in Alberta. Can. J. Genet. Cytol., 25, 57-64.

EFRON, B. AND TIBSHIRANI, R. 1991. Statistical data analysis in the computer age. Science, 253 390-395.

EPPERSON, B. K. AND ALLARD, R. w. 1989. Spatial autocorrelation analysis of the distribution of genotypes within populations of lodgepole pine. Genetics, 121, 369-377.

EPPERSON, B. K. AND CLEGG, M. T. 1986. Spatial autocorrelation analysis of flower color polymorphisms within substructured populations of morning glory (Ipomoea purpurea). Am. Nat., 128, 840-858.

FRIPP, Y. J., GRIFFIN, A. R. AND MORAN, G. F. 1987. Variation in allele frequencies in the outcross pollen pool of Eucalyptus regnans $\mathrm{F}$. Muell. throughout a flowering season. Heredity, 59, 161-171.

GARDiner, A. s. 1970. Pedunculate and sessile oak (Quercus robur L. and Quercus petraea (Matt.) Liebl.). A review of the hybrid controversy. Forestry, 43, 151-160.

GARDNER, J. P. A. 1992. Null alleles and heterozygote deficiencies among mussels (Mytilus edulis and M. galloprovincialis) of two sympatric populations. Malacologia, 34, 99-106.
GREGORIUS, H.-R., KRAUHAUSEN, J. AND MÜLLER-STARCK, G. 1986. Spatial and temporal genetic differentiation among the seeds in a stand of Fagus sylvatica L. Heredity, 57, 255-262.

HAMRICK, J. L., GODT, M. J. W. AND SHERMAN-BROYLES, S. L. 1992 , Factors influencing levels of genetic diversity in woody plant species. New Forests, 6, 95-124.

HEYWOOD, J. S. 1991. Spatial analysis of genetic variation in plants. Ann. Rev. Ecol. Syst., 22, 335-355.

JENSEN, T. S. AND NIELSEN, O. F. 1986. Rodents as seed dispersers in a heath-oak wood succession. Oecologia., 70, 214-221.

KNOWLES, P. 1991. Spatial genetic structure within two natural stands of black spruce (Picea mariana (Mill.) B.S.P.). Silvae Genetica, 40, 13-19.

KREMER, A., PETIT, R., ZANETTO, A., FOUGERE, V., DUCOUSso, A., WAGNER, D. AND CHAUVIN, C. 1991. Nuclear and organelle gene diversity in Quercus robur and Quercus petraea. In: Müller-Starck, G. and Ziehe, M. (eds) Genetic Variation of Forest Tree Populations in Europe. pp. 141-166. Sauerländer Verlag, Berlin.

LEDIG, F. T. AND CONKLE, M. T. 1983. Gene diversity and genetic structure in a narrow endemic, torrey pine (Pinus torreyana Parry ex Carr.). Evolution, 37, 79-85.

LEVIN, D. A. AND KERSTER, H. W. 1974. Gene flow in seed plants. Evol. Biol., 7, 139-220.

MÜLLER-STARCK, G. AND ZIEHE, M. 1991. Genetic variation in populations of Fagus sylvatica L., Quercus robur L. and $Q$. petraea Liebl. in Germany. In: Müller-Starck, G. and Ziehe, M. (eds) Genetic Variation of Forest Tree Populations in Europe, pp. 125-140. Sauerländer Verlag, Berlin.

ODEN, N. L. 1984. Assessing the significance of a spatial correlogram. Geogr. Analysis, 16, 1-16.

PERRY, D. J. AND KNOWLES, P. 1991. Spatial genetic structure within three sugar maple (Acer saccharum Marsh.) stands. Heredity, 66, 137-142.

RITLAND, K. 1985. The genetic-mating structure of subdivided populations. I. Open-mating model. Theor. Pop. Biol., 27, $51-74$.

RUSHTON, B. S. 1993. Natural hybridization within the genus Quercus L. In: Kremer, A., Savill, P.S. and Steiner, K.C. (eds) Genetics of Oaks, pp. 73-90. Elsevier, Paris.

SAMPSON, J. F., HOPPER, S. D. AND JAMES, S. H. 1990. Temporal variation in allele frequencies in the pollen pool of Eucalyptus rhodantha. Heredity, 65, 189-199.

SCHMIDTLING, R. C. 1981. The inheritance of precocity and its relationship with growth in loblolly pine. Silvae Genetica, 30, 188-192.

ŠIDAK, Z. 1967. Rectangular confidence regions for the means of the multivariate normal distribution. J. Am. Stat. Assoc., 62, 626-633.

SLATKIN, M. AND ARTER, H. E. 1991. Spatial autocorrelation methods in population genetics. Am. Nat., 138, 499-517.

SOKAL, R. R. 1978. Population differentiation: something new or more of the same? In: Brussard P.F. (ed.) Ecological Genetics: the Interface, pp. 215-239. Springer-Verlag, Berlin.

SOKAL, R. R. AND ODEN, N. L. 1978. Spatial autocorrelation in biology. 1. Methodology. Biol. J. Linn., 10, 199-228.

SOKAL, R. R. AND ROHLF, F. J. 1981. Biometry. 2nd edn. Freeman, New York. 
SORK, V. L. 1984. Examination of seed dispersal and survival in red oak, Quercus rubra (Fagaceae), using metal-tagged acorns. Ecology, 65, 1020-1022.

SORK, V. L., HUANG, S. AND WIENER, E. 1993. Macrogeographic and fine-scale genetic structure in a North American oak species, Quercus rubra L. In: Kremer, A., Savill, P.S. and Steiner K.C. (eds) Genetics of Oaks, pp. 261-270. Elsevier, Paris.

SQUILLACE, A. E. 1974. Average genetic correlations among offspring from open-pollinated forest trees. Silvae Genetica, 23, 149-156.

STEINHOFF, s. 1993. Results of species hybridization with Quercus robur L. and Quercus petraea (Matt) Liebl. In: Kremer, A., Savill P.S. and Steiner, K.C. (eds) Genetics of Oaks, pp. 137-143. Elsevier, Paris.

SWEET, G. B. 1975. Flowering and seed production. In: Faulkner, R. (ed.) Seed Orchards. Forestry Commission Bulletin, 54, 72-82.

VALLEJOS, C. E. 1983. Enzyme activity staining in isozymes. In: Tanksley, S.D. and Orton, T.J. (eds) Plant Genetics and Breeding. Part A, pp. 469-515. Elsevier Science Publishers, Amsterdam.
WAGNER, D. B., SUN, Z. X., GOVINDARAJU, D. R. AND DANCIK, B. P. 1991. Spatial patterns of chloroplast DNA and cone morphology variation within populations of a Pinus banksiana-Pinus contorta sympatric region. Am. Nat., 138, 156-170.

WEIR, B. S. AND COCKERHAM, C. C. 1984 . Estimating $F$-statistics for the analysis of population structure. Evolution, 38, 1358-1370.

WHEELER, N. C. AND GURIES, R. P. 1982. Population structure, genic diversity, and morphological variation in Pinus contorta Dougl.. Can. J. For. Res., 12, 595-606.

WRIGHT, s. 1943. Isolation by distance. Genetics, 28, 114-138.

WRIGHT, s. 1978. Evolution and the Genetics of Populations, vol. 4, Variability Within and Among Natural Populations. University of Chicago Press, Chicago.

ZANETTO, A., KREMER, A. AND LABBE, T. 1993. Differences of genetic variation based on isozymes of primary and secondary metabolism in Quercus petraea. In: Kremer, A., Savill, P.S. and Steiner K.C. (eds) Genetics of Oaks, pp. 245-252. Elsevier, Paris. 